\title{
elites políticas e alternativas de desenvolvimento na redemocratização de 1945-1946
}

Sérgio Soares Braga

Universidade Federal do Paraná

\begin{abstract}
RESUMO
Análise dos debates em torno das alternativas de desenvolvimento ocorridos no contexto da redemocratização de 1945/46 e da Constituinte de 1946, bem como da atuação das mais importantes lideranças empresariais e burocráticas no período, Tentativa de demonstrar como os resultados de um levantamento prosopográfico das elites políticas e econômicas, e a análise qualitativa da biografia e da ação parlamentar dos atores políticos relevantes no período, nos fornecem subsídios analíticos que possibilitam reinterpretar a relação entre o Estado, o desenvolvimento econômico e o sistema partidário do imediato pós-guerra no Brasil.
\end{abstract}

Palavras-chave: elites políticas e econômicas, processo de redemocratização, desenvolvimentismo,luta de classes, biografias coletivas.

\begin{abstract}
Analysis of the debates about the development alternatives which occurred in the context of the $1945 / 46$ redemocratization process and within the 1946 Constituent Assembly, as well as of performance of some of the period's most important entrepreneurial and bureaucratic leaders. Attempt to demonstrate how the results of a prosopographic survey of the political and economic elites, together with the qualitative analysis of the biographies and parlamentary actions of the period's relevant political actors may provide the analytical means for reconsidering the relationships among the State, the economic development and the Party System of the Second World War's immediate aftermath in Brazil.

Key words:political and economical elites, redemocratization process, developmentalism, class struggle, collective biographies.
\end{abstract}

Este artigo é uma versão revista e significativamente ampliada da comunicação "Elites políticas e alternativas de desenvolvimento na redemocratização de 19451946: reflexões sobre a utilização do método prosopográfico em História do Brasil", por nós apresentada durante o XXI Simpósio Nacional de História da A N P UH (A História no Novo Milênio: entre o individual e o coletivo) realizado na cidade de $\mathrm{Ni}$ terói-RJ emjulho de 2001. Agradeço aos professores Flávio Heinz (Departamento 


\section{Introdução}

Em trabalho anterior (Braga, 1998)² buscamos, além de fornecer uma descrição exaustiva da origem social, da trajetória política e da atuação político-parlamentar das lideranças políticas atuantes na Assembléia Constituinte de 1946, empreender uma reflexão de natureza teórica e metodológica, cujo núcleo eram as possibilidades e os limites dos estudos que se situam dentro da problemática do "recrutamento das elites"para uma compreensão mais ampla da atuação das lideranças políticas no período, especialmente para o estabelecimento de relações de representação ou de conexões comportamentais entre lideranças políticas e determinados interesses coletivos (organizados ou não) existentes numa dada conjuntura histórica. Chegamos à conclusão de que esse estudo do recrutamento de tais vanguardas políticas desempenhava importante papel para o estabelecimento de tais conexões, desde que fosse utilizado ao lado de outros procedimentos teórico-metodológicos complementares. Ou, como afirmamos naquele nosso trabalho:

(...) Assim, para estabelecermos tais conexões, as informações expostas acima [nas tabelas que sistematizavam os resultados de nossa pesquisa sobre as lideranças partidárias no imediato pós-guerra] só nos são úteis a título de uma "primeira aproximação" para a análise do sistema partidário. Para avançarmos no estabelecimento de tais relações, é necessário empregar uma metodologia mais completa e abrangente, que trabalhe num menor nível de agregação, e que capte, dentre outros, os seguintes elementos fundamentais:

(i) Análise da estrutura de classes e da dinâmicas das lutas sociais no período; caracterização das demandas sociais existentes entre as diferentes classes, agrupamentos, grupos e subgrupos sociais;

(ii) Análise do sistema partidário e das organizações internas dos diferentes partidos, mormente das concepções ideológico-programáticas dos líderes organizacionais das diferentes agremiações;

de História da Unisinos), coordenador da mesa, e Cláudia Maria Ribeiro Viscardi (Departamento de História da UFJF) pelas observações feitas por ocasião do encontro, os quais não são, evidentemente, responsáveis pelos eventuais equívocos remanescentes no texto.

Braga (1998). A versão on-line deste livro está disponível no site da Câmara dos Deputados: camara.gov.br $\longrightarrow$ [Documentação e Informação] $\longrightarrow$ [Publicações Eletrônicas]. 
(iii) Exame da natureza das ligações destes líderes organizacionais com os diversos agregados de interesse e instituições-chave existentes numa sociedade qualquer;

(iv) Análise do conteúdo da ação política (programas, estratégias, ideologias etc.) dos diferentes partidos no transcurso dos trabalhos parlamentares e em outras dimensões da vida partidária, a fim de estabelecer em que medida a prática efetiva dos partidos correspondeu às demandas e expectativas dos grandes agregados de interesse existentes 'fora' do parlamento" (Braga, 1998: 89).

Ou seja, procurávamos, seguindo idéias contidas em autores críticos ao chamado "paradigma das elites", apontar os limites e deficiências metodológicas dos estudos correntes sobre o assunto, destacando os levantamentos predominantemente quantitativos e descritivos, que não servem de base de apoio para um exame mais aprofundado e abrangente do conteúdo da ação social de tais atores. Esclarecemos então que essa quase sociografia descritiva das lideranças políticas e econômicas só tem alguma utilidade e potencial heurístico se nos servir como base empírica de apoio (uma "primeira aproximação") para uma análise mais profunda dos processos políticos nos quais estas elites interagem, análise esta que busque estabelecer conexões entre a ação de tais atores individuais ou grupos de atores, e os contextos sócio-políticos mais amplos que servem de moldura e imprimem significação a tais ações, tornando-as "orgânicas" ou socialmente enraizadas, selecionando-as da miríade de práticas e atitudes que estruturam cada existência individual. Co m efeito, diversas análises políticas e historiográficas buscam solucionar esses problemas recorrendo ao método "prosopográfico" e demonstrando uma

Conforme a definição clássica da Lawrence Stone (1972) "A prosopografia é a investigação das características comuns do passado de um grupo de atores na história através do estudo coletivo de suas vidas. O método empregado consiste em definir um universo a ser estudado e então a ele formular um conjunto de questões padronizadas - sobre nascimento e morte, casamento e família, origens sociais e posições econômicas herdadas, local de residência, educação e fonte de riqueza pessoal, ocupação, religião, experiência profissional e assim por diante(...). O propósito da prosopografia é dar sentido à ação política, ajudar a explicar a mudança ideológica ou cultural, identificar a realidade social, descrever e analisar com precisão a estrutura da sociedade e o grau e a natureza dos movimentos que se dão no seu interior". Segundo observa outro autor: "Embora talvez nem todos os especialistas concordem com isso, podemos considerar a prosopografia, ou o método das Biografias Coletivas (os termos são comumente intercambiáveis, sobretudo em se tratando de seu uso em história contemporânea), como um método que utiliza um approach de 
maior preocupação com o levantamento qualitativo da trajetória e da atuação das lideranças políticas e econômicas, com vistas a: (i) estabelecer conexões entre a atividade das elites políticas e certos interesses coletivos enraizados em outras esferas da vida social, não obstante a autonomia estratégica e a irredutibilidade da ação desses atores a meras clivagens "societais"; (ii) analisar de forma mais aprofundada o conteúdo da ação de tais vanguardas (burocráticas, empresarias, sindicais etc), apreendendo as decisões relevantes destes agentes históricos através de recursos metodológicos padronizados que possibilitem a análise comparativa das semelhanças e eventuais diferenças da ação política desses grupos de atores.

No presente trabalho, buscaremos avançar nesta direção, concentrando-nos primordialmente nos debates travados em torno dos modelos de desenvolvimento capitalista a serem implementados na formação social brasileira no imediato pós-Guerra. Dada a impossibilidade de abordar aqui todos os aspectos teóricos e metodológicos envolvidos na operacionalização dessa perspectiva de análise, tomaremos como objeto de análise os debates em torno das alternativas de desenvolvimento ocorridos no contexto da redemocratização de 1945-1946 e da Constituinte de 1946, bem como a atuação de algumas das mais importantes lideranças empresariais e burocráticas no período,procurando demonstrar, através do exame de tais debates, como os resultados do levantamento prosopográfico das lideranças políticas e econômicas, e a análise qualitativa da biografia e da ação parlamentar de alguns atores políticos relevantes no período, nos fornecem subsídios analíticos que possibilitam reinterpretar alguns aspectos da relação entre economia e sociedade no imediato pós-guerra (1945-1946) no Brasil.

Com vistas a abordar estas questões, adotaremos como referência para a organização das informações coletadas durante a pesquisa a periodização e o esquema analítico desenvolvidos por Ricardo Bielschowsky em seu trabalho sobre o "ciclo ideológico do desenvolvimentismo" no

tipo sociológico em pesquisa histórica, buscando revelar as características comuns (permanentes ou transitórias) de um determinado grupo social em dado período histórico. As biografias coletivas ajudam a elaborar perfis sociais de determinados grupos sociais, categorias profissionais ou coletividades históricas, dando destaque aos mecanismos coletivos - de recrutamento, seleção e de reprodução social - que caracterizam as trajetórias sociais (e estratégias de carreira) dos indivíduos" [passagem extraída da Home Page do professor Flávio Heinz: http://www.humanas. unisinos.br/professores/heinz/]. 
pós-30 (Bielschowsky, 1988), e como artifício metodológico o acompanhamento intensivo da atuação ideológica e parlamentar de algumas lideranças políticas "típicas" das várias correntes "desenvolvimentistas" e "antidesenvolvimentistas" do período, tais como Souza Costa (PSDRS), Agamenon Magalhães (PSD-PE), Daniel de Carvalho (PR-MG), Alde Sampaio (UDN-PE), Sampaio Vulal (PSD-SP), Israel Pinheiro (PSD-MG), Segadas Viana (PTB-DF), Luiz Carlos Prestes (PCB-DF), dentre outras. Entretanto, antes de adentrarmos no exame de tais debates, convém mencionar, ainda que brevemente, o contexto político e econômico mais amplo no qual os mesmos ocorreram.

\section{A crise do Estado Novo e a redemocratização de 1945-46}

Para os fins deste artigo, basta destacar que as discussões ocorridas na Constituinte de 1946 foram um "momento" dos amplos e intensos conflitos e debates políticos envolvendo as diferentes correntes de pensamento econômico que determinaram, e foram simultâneos ao contexto de crise do Estado Novo - debates estes cujo marco inicial pode ser considerado a realização do I Congresso Brasileiro de Economia no Rio de Janeiro, em novembro/dezembro de 1943, organizado sob os auspícios da Associação Comercial do Rio de Janeiro (ACRJ), o qual contou com a participação de diversas associações de classe representativas de variados segmentos empresariais." Nesse Congresso, após um longo período de "debate interditado" pela ditadura estadonovista, os diversos segmentos dos grupos dominantes nacionais vieram a público expor seus pontos de vista sobre temas econômicos, muitos deles inclusive divergentes das diretrizes econômico-financeiras então implementadas pelo Governo Central.

Como pode ser verificado pela leitura dos Anais da Assembléia Constituinte de 1946 e dos Diários do Congresso Nacional, ${ }^{5}$ estes confrontos repercutiram intensamente no processo de elaboração constitucional, bem como nos trabalhos legislativos posteriores. Um elemento que re-

Para uma reconstituição mais detalhada de todo esse processo, veja-se o importante trabalho de Corsi (1991).

Vale destacar que a Câmara dos Deputados talvez seja o único órgão parlamentar do mundo que disponibiliza a íntegra de todos os seus Diários e Anais parlamentares, on-line e digitalizados para a consulta pública, durante todo o período histórico de seu funcionamento, desde o Império. Cf. o site da Câmara dos Deputados, item Diários: www.camara.gov.br 
forçou essa repercussão foi o fato de importantes lideranças políticas do período (tanto do setor estatal como do privado), que participaram ativamente desses debates, terem sido eleitas para a primeira legislatura do pós-Guerra na legenda de diferentes partidos. ${ }^{6}$ Assim, o contexto político da época (redemocratização sucedendo a uma ditadura que concentrou o confronto de idéias sobre temas econômicos no interior de órgãos governamentais), somado à presença de importantes lideranças políticas envolvidas, a diversos títulos e graus, no debate econômico do período, fez com que a Assembléia Constituinte de 1946, e a legislatura ordinária que a ela se seguiu, se transformassem num importante palco de debates sobre temas econômicos.

Do ponto de vista da conjuntura econômica, essa foi uma fase de definição dos rumos da economia brasileira e de adaptação desta ao novo contexto internacional pós-Bretton Woods, que marcaria toda a dinâmica econômica do pós-guerra (Malan, 1980). Como demonstram estudos recentes (Abreu, 1994; Corsi, 2000), após uma fase inicial em que se esboçou a formulação de uma estratégia de desenvolvimento capitalista mais "autônoma" no início do Estado Novo, entre os anos de 1937 e 1939, as autoridades governamentais encarregadas da formulação da política econômica, pressionadas pelas dificuldades de financiar

Por exemplo, dentre essas lideranças destacam-se, para o setor público: o próprio ex-ministro da Fazenda (1934-1945) Souza Costa, eleito pelo PSD/RS; Israel Pinheiro (PSD/MG), político estritamente ligado à cúpula burocrática estadonovista e primeiro presidente da Cia.Vale do Rio Doce; Benedito Valadares (PSD/MG), ex-interventor de MG (1937-1945) durante o regime estadonovista; Marcondes Filho (PTB/SP), ministro do Trabalho de Vargas no transcurso do Estado Novo; Barbosa Lima Sobrinho (PSD/PE), ex-presidente do Instituto do Açúcar e do Álcool (1939-1945).

Dentre as lideranças políticas representativas de várias frações empresariais, destacam-se Daniel de Carvalho que, embora eleito pelo PR/MG, estava radicado no Rio de Janeiro, onde era diretor da filial mineira do Banco Industrial de Minas Gerais e presidente do Instituto de Pesquisas Econômicas da Associação Comercial do Rio de Janeiro; Alde Sampaio (UDN/PE), líder patronal dos usineiros pernambucanos e atuante em diversas associações de classe de vários setores empresariais; o banqueiro Magalhães Pinto (UDN/MG), ex-presidente da Associação Comercial de Minas Gerais; Sampaio Vidal (PSD/SP), cafeicultor e presidente da Sociedade Rural Brasileira durante o Estado Novo (1943-1945); Horácio Lafer (PSD/SP), diretor do CIESP e da FIESP e uma das principais lideranças industriais do póstrinta. Mais informações sobre a trajetória política e a atuação parlamentar das personalidades mencionadas nesta e em outras partes do artigo podem ser encontradas na nova edição do Dicionário Histórico-Biográfico Brasileiro pós-1930 do C P D O C / FGV (Abreu et. al. Coord., 2001) e, principalmente, em Braga (1998). 
o processo de industrialização acelerada, bem como pelas vicissitudes da inserção do Brasil na nova configuração geopolítica internacional gerada pela eclosão da II Guerra Mundial, optaram por um alinhamento crescente (político e econômico) com os EUA. Esse alinhamento geral, no entanto, não eliminou as fricções e os conflitos entre setores dos governos norte-americano e brasileiro no tocante a várias medidas governamentais - como, por exemplo, as medidas destinadas a viabilizar a redemocratização do País e, no plano econômico, questões tais como a política de preços do café, controle sobre importações, todas relacionadas ao ritmo mais ou menos intenso do processo de industrialização acelerada implementado no Brasil (Abreu, 1994).

Neste sentido, a série de medidas nacionalistas decretadas por Vargas no caso do regime estadonovista, mais do que atestar uma eventual tendência hegemônica nas cúpulas governistas no sentido da implantação de um modelo de desenvolvimento capitalista "autônomo" no País, configurava-se como uma estratégia política de radicalização riacionalpopulista de setores subalternos da cúpula governamental e da burocracia de estado, entre os quais se incluía o próprio presidente Vargas.' Tal estratégia era, essencialmente, uma resposta de círculos políticos e econômicos mais próximos de Getúlio às pressões advindas de vários segmentos sociais (pressões ocasionadas por motivos diversos, mas que geraram como efeito compósito comum a crise da ditadura estadonovista) ao quadro institucional e a alguns aspectos de matiz mais nacionalista da política econômica implementada durante o Estado Novo (Braga, 1996; Corsi, 1991; 2001).

Dentro dessa perspectiva, o significado político da derrubada de Getúlio Vargas a 29 de outubro de 1945, assim como da posterior vitória de Eurico Dutra para a presidência da República, reside num afastamento, dos centros decisórios encarregados da formulação da política econômica daquelas elites políticas e econômicas mais comprometidas com uma plataforma"desenvolvimentista-nacionalista" como estratégia

Além da "lei malaia", decretada em junho de 1945 e que está estritamente relacionada ao afastamento de Vargas poucos meses depois, devemos destacar a Portaria Interministerial $\mathrm{n}^{\circ} 7$, estabelecendo severas restrições às importações de produtos "suntuários e dispensáveis", e instituindo a Comissão de Estudo das Importações, destinada a classificar os produtos nas categorias de bens essenciais e supérfluos e estabelecendo listas a partir das quais seria realizado o licenciamento das importações. Como se sabe, tal medida causou forte oposição do governo norte-americano e foi revogada após o fim da ditadura estadonovista, durante o governo de transição de José Linhares pela Resolução Interministerial 258 de 28.12.1945 (Corsi, 2000: 269). 
econômica mais adequada para nortear o desenvolvimento capitalista brasileiro no pós-Guerra. Atemorizados pela guinada à esquerda das forças getulistas, bem como pelo crescimento do movimento dos trabalhadores e dos comunistas no ocaso da ditadura estadonovista, ${ }^{8}$ setores do Exército, chefiados por Góis Monteiro e Dutra,"optaram" por uma estratégia de transição para o regime político democrático diversa daquela escolhida por Vargas e seu staff, decidindo por um recuo nas medidas econômicas "nacional-desenvolvimentistas" decretadas no período, simultaneamente à articulação de um compromisso com frações das classes dominantes (especialmente a burguesia comercial-bancária e proprietários de terra agro-exportadores) de oposição ao regime e ao recrudescimento da repressão ao movimento popular.

No acordo conjuntural feito por estas várias forças sociais (UDN, Forças Armadas, governo norte-americano, frações anti-varguistas das classes dominantes) para derrubar Vargas a 29 de outubro,já estavam embutidos, em embrião, os "compromissos" e "coalizões" que caracterizam o governo Dutra, bem como as diretrizes fundamentais que norteariam a ação desse governo, principalmente na sua fase inicial, quais sejam: a) repressão sistemática às forças progressistas e populares; b) alinhamento estrito com os EUA no plano da política externa; c) política econômica de desregulamentação estatal e de maior abertura ao exterior (extinção de agências estatais de regulação econômica, término da licença prévia para importações etc); d) "pacificação geral" no seio dos grupos dominantes - ou seja, no interior das várias frações burocráticas e das classes dominantes que disputavam entre si o controle sobre os centros de poder formuladores da política econômica da época.'

* É bom lembrar que, além de ter sido um período de grande crescimento do PCB, essa fase histórica caracterizou-se também pelo recrudescimento do movimento grevista e sindical, destacando-se a criação do MUT (Movimento Unificador dos Trabalhadores), embrião da organização da Confederação Geral dos Trabalhadores Brasileiros (CGTB), que viria a ser fechada pouco depois pelo governo Dutra.

Foi por esse motivo que a cassação do PCB ocorreu simultaneamente ao "acordo interpartidário" PSD/UDN/PR, o qual foi o responsável pela difusão do mito de que o governo Dutra teria sido um período de "paz social", quando na realidade se caracterizou por uma repressão sistemática aos trabalhadores e suas organizações. Esse foi o motivo também pelo qual destacados membros da nova equipe governamental de Dutra (como o ministro da Fazenda, Gastão Vidigal, os ministros da Agricultura, Daniel de Carvalho, e da Educação, Clemente Mariani) possuíam amplas ligações com frações empresarias de oposição ao regime estadonovista. Desnecessário dizer que a política econômica da fase inicial do governo Dutra - isto é, anterior 
É nesse contexto político-econômico que começou a funcionar o parlamento encarregado de formular a nova Constituição e assentar os pilares do novo sistema político a ser organizado no pós-guerra, com a U D N e as forças liberais derrotadas nas urnas, o movimento popular e comunista em ascensão, o imperialismo norte-americano pressionando no sentido de um recuo das medidas industrializantes e nacionalistas adotadas durante o Estado Novo, e a facção hegemônica da burocracia estatal (capitaneada pelos generais Eurico Dutra e Góis Monteiro) procurando por todos os meios "costurar" um acordo com os segmentos mais conservadores das classes dominantes e com a forças oposicionistas, a fim de reprimir com maior segurança e eficácia o movimento popular e o PCB. Por sua vez, o rápido crescimento das organizações populares era um sintoma das amplas pressóes redistributivas represadas durante o Estado Novo, e que vieram a se manifestar no sistema político no breve interregno de legalização do PCB, através de uma intensificação da luta de classes (Bielschowsky, 1988).

Dentro desse quadro, as questões básicas que iriam pautar o debate econômico brasileiro no pós-Guerra (tais como: posicionamento em relação ao intervencionismo estatal, capital estrangeiro, medidas redistributivas, receitas "ortodoxas" ou "heterodoxas" de controle da inflação, reforma agrária etc.) emergiram no seio do sistema político e polarizaram as atenções das lideranças político-partidárias, conforme procuraremos demonstrar nas páginas que seguem. ${ }^{10}$

à restauração da licença prévia para importações em 1947-1948, foi a expressão de toda essa correlação de forças.

"Para uma reconstituição detalhada de todo o contexto político e econômico subjacente aos debates parlamentares aqui analisados, cf. o item II.1 "O pensamento econômico na transição do pós-guerra: o liberalismo e a resistência desenvolvimentista - 1945/47", do trabalho já citado de Bielschowsky (1988: 303-366). A consulta a tais páginas é fundamental para a compreensão das questões tratadas nesse artigo, bem como para o contexto no qual ocorreram os debates examinados a seguir. Entretanto, divergimos desse autor quando encampa, em algumas passagens, teses recorrentes na literatura sobre o período, segundo as quais teria havido um "predomínio da corrente liberal" no pensamento econômico da época e na fase inicial do governo Dutra. Segundo nosso ponto de vista, menos do que uma "restauração liberal", como querem alguns, a fase inicial do governo Dutra expressaria esse contexto de atenuação dos conflitos intra-bloco no poder, responsável pelo clima político de "concessões mútuas" entre os vários segmentos das cúpulas burocráticas e das classes dominantes, para fazer frente ao crescimento do movimento popular e do $\mathrm{PCB}$, bem como às exigências da inserção política mundial da formação social brasileira na arena internacional do pós-guerra.Tais fatores foram responsáveis 


\section{Lideranças políticas, partidos e o debate econômico}

Tomando como base o "quadro síntese" sugerido por Ricardo Bielschowsky em seu estudo sobre o ciclo ideológico do desenvolvimentismo no pós-trinta, podemos verificar que a atuação parlamentar de algumas das principais lideranças atuantes na época encaixa-se no esquema classificatório elaborado por aquele autor."

A primeira grande corrente de pensamento econômico representada no sistema partidário da época era a neoliberal. Dados os limites de espaço, destacaremos apenas algumas de suas principais características enunciadas por Bielschowsky ao longo de seu trabalho (1988: 44 e passim). Os neoliberais: a) opunham-se à intervenção do Estado na economia; b) eram favoráveis a políticas de equilíbrio monetário e financeiro, evitando a discussão sobre seus efeitos sobre o nível de renda e emprego; c) não propunham medidas de suporte ao projeto de industrialização e eram freqüentemente contrários a essas medidas. No plano do sistema partidário organizado no imediato pós-guerra, essa corrente estava representada por setores minoritários (mas com grande influência política) do PSD, boa parcela da UDN e por setores majoritários do PR. Analisando a biografia e a trajetória política de algumas de suas principais lideranças, podemos perceber que a maior parte delas tinha amplas ligações com os setores comerciais, bancários e do ramo de seguros, com segmentos agro-exportadores produtores de commodities, e com segmentos das altas camadas médias "tradicionais", ou da pequeno-burguesia intelectualizada e dependente financeiramente desses setores da classe dominante, em processo de acentuada perda de prestígio social após a expansão do capitalismo e da "nova burocracia de Estado" brasileira no pós-trinta.'

pelo "recuo" estratégico das cúpulas governamentais desenvolvimentistas, recuo este responsável pela ilusão de ótica segundo a qual teria havido uma "restauração neoliberal" no período.

Para uma visão abrangente e sintética das principais correntes de pensamento econômico no período, cf. o "Quadro-síntese das correntes de pensamento econômico atuantes no período 1945/64", elaborado por Bielschowsky (1988: 284-285), onde são apresentadas resumidamente as características das correntes básicas de pensamento econômico na época, ou seja, as correntes Neoliberal, Desenvolvimentista do Setor Privado, Desenvolvimentista Nacionalista (Setor Público), Desenvolvimentista Não-Nacionalista (Setor Público) e Socialista.

12 Cf. o texto de Miceli (1986), sobre esse interessante processo social, bem com sobre a aliança desses vários segmentos sociais. 
$\mathrm{Na}$ Constituinte de 1946, as principais lideranças neoliberais eram constituídas por parlamentares como Jales Machado (UDN-GO), Artur Bernardes (PR-MG), Daniel de Carvalho (PR-MG), Clemente Mariani (UDN-BA), SampaioVidal (PSD-SP), dentre outros. Como nos informa Ricardo Bielschowsky, Daniel de Carvalho foi o "economista neoliberal mais radical de sua época" (1988: 315). Acompanhando a atuação deste parlamentar podemos qualificar melhor em que consiste seu "radicalismo" neoliberal.

Uma das ocasiões em que essa argumentação neoliberal se expressa com maior clareza é no parecer de Daniel de Carvalho à Indicação n. 173-A do industrial e "desenvolvimentista do setor privado" Horácio Lafer (PSD-SP), sugerindo a "criação de um órgão destinado a incrementar a cultura de trigo" de cunho essencialmente "desenvolvimentista", pois solicitava a intervenção do Estado para sustentar "artificialmente" um processo tipicamente "substitutivo de importações", e que redundaria na formação de um complexo agro-industrial votado para a produção para o mercado interno.

Vejamos alguns trechos do parecer de Daniel Carvalho:

"A primeira observação que ocorre após a leitura da indicação é que ela aconselha a criação de mais um órgão paraestatal de economia dirigida, mais um instituto, mais uma intervenção direta do Estado na economia nacional, mais um aparelho de compressão da liberdade econômica com inevitável reflexo no campo das liberdades políticas. Ora, na Carta de Teresópolis, as classes produtoras reconheceram que a ordem econômica brasileira se funda no princípio da liberdade e no primado da iniciativa privada, cabendo ao Estado criar condições favoráveis ao desenvolvimento das liberdades privadas, animá-las, auxiliá-las, facilitar-lhes a organização e prestar-lhes assistência técnica. Só excepcionalmente exerceria o Estado ação direta para suprir as deficiências da iniciativa particular. (...)

A indicação padece ainda de outro grave defeito, qual seja o de não levar em conta as vantagens da divisão do trabalho entre os povos e os benefícios derivados do comércio internacional. Alastrase entre nós, pela ignorância dos princípios da ciência econômica, a crença de que, se podemos produzir trigo, devemos produzir este cereal, libertando-nos assim da dependência de países estrangeiros quanto a este artigo essencial à alimentação do povo. (...)

$O$ intercâmbio de mercadorias constitui uma necessidade inerente à diversidade das condições de cada país. Baseia-se na utilização mais 
produtiva do trabalho do capital e dos recursos naturais. Fruto da especialização, o comércio internacional concorre para aumentar a renda e o padrão de vida de cada povo.

Nessa matéria, continua a dominar a teoria clássica dos custos comparativos de Ricardo, com os esclarecimentos e modificações nela introduzidas pelos seus sucessores (Mill, Marshall, Ohlin, Haberler,Taussig etc). Entre os efeitos do comércio internacional, avulta o da utilização mais eficiente dos fatores de produção, de modo que cada país se beneficia com a especialização geográfica e adquire, assim, maior lucro real. (...)

A indicação também não teve em vista a situação em que se encontra o Brasil de pleno emprego dos fatores de produção, objeto de pacientes estudos do professor Eugênio Gudin.

Segundo o primeiro princípio formulado por este mestre perante a Comissão de Planejamento Econômico, 'uma vez atingido o emprego total, novos empreendimentos farão subir os preços mas não farão crescer a produção" (Anais da Constituinte, vol. XX: 329-331)

Sublinhe-se que Daniel de Carvalho era um dos intelectuais mais influentes da época, presidente do Instituto de Economia da Associação Comercial do Rio de Janeiro e com várias ligações nos meios empresariais bancário-mercantis da região centro-sul do Brasil.

Ao lado destes, vários outros discursos de parlamentares integrantes da corrente "neoliberal", também foram proferidos durante os trabalhos constituintes. Por exemplo, em abril de 1946, o ex-presidente da República Artur Bernardes profere dois discursos sobre o "Funcionamento e prejuízo das instituições autárquicas" (Anais, V; 287-289), que são verdadeiros libelos contra as autarquias e a política de intervenção do Estado na economia:

"Essas instituições autárquicas (refere-se ao DNC, IAA etc.) são obsoletas, antiquadas, arcaicas mesmo e se achavam sepultadas na noite dos tempos, onde o Estado Novo foi desenterrá-las, não para servir à economia nacional, mas para atrelar ao carro da ditadura as classes tidas como independentes. Já há muito haviam sido abandonadas pela humanidade que, na sua marcha evolutiva para o progresso e para a civilização, atingira estágios mais avançados, como os da livre concorrência e o da lei da oferta e da procura. (...) Quando a humanidade pôs de lado esses processos empíricos havia observado que ao Estado faltava aptidão para gerir os negócios, os interesses econômicos. 
(Muito bem). Sem embargo, nada faltou, nos últimos anos, ao nosso desventurado país, inclusive a ressurreição dessa velharia que tamanha desgraça viria a causar ao povo e à economia brasileira" (V: 288).

Também a defesa da entrada do capital estrangeiro na economia era uma constante no discurso dos neoliberais.Por exemplo, em pronunciamento feito na $34^{\star}$ sessão da Assembléia Constituinte, em 27 de março de 1946, o cafeicultor e líder rural da UDN goiana, Jales Machado (UDN-GO), replica a um discurso pronunciado por Prestes, no qual este criticava a forma de penetração do capital estrangeiro na economia brasileira e o imperialismo norte-americano. Jales Machado defende veementemente o capital estrangeiro, especialmente o norte-americano, e expõe as razões para tal defesa:

"O Sr. Carlos Prestesjulga ser quase um crime a saída das rendas do capital estrangeiro invertido em nosso país e de que, inegavelmente, tanto nos temos beneficiado econômica e socialmente. Se ele acha que esses rendimentos não são úteis ao país, não poderá negar que o capital de que eles provieram [sic.] tem sido, são e serão do nosso mais profundo interesse. Se assim é, e não poderá deixar de ser, o que precisamos fazer é garantir essa liberdade de saída das rendas para que a política contrária [à livre entrada e saída de capitais estrangeiros - SSB] não afugente os capitais tão necessários ao nosso progresso.

E há ainda mais: esses capitais arrastam consigo valioso contingente humano representado pelos técnicos e operários especializados que têm sido verdadeiras escolas profissionais para os operários brasileiros. Dessas escolas provieram os primeiros tecelões, mecânicos, montadores e demais artífices das primeiras indústrias brasileiras, fruto do capital estrangeiro. O parque industrial de São Paulo seria o que é hoje sem o concurso do braço italiano que o capital arrastou para o Brasil? [seguem-se outras perguntas do gênero]

A meu ver, é profundamente contrário aos interesses nacionais, também, a idiossincrasia, tantas vezes proclamada, de sua Ex." pelo Estados Unidos. Deles nos tem vindo tudo, desde o estímulo à nossa independência até o modelo de nossa democracia. Temos vivido sempre na sua dependência financeira e econômica, podemos dizer na sua proteção, e nunca arranharam nossa soberania. Pelo contrário, a têm prestigiado".

E, mais à frente, explicitando as razões desse apoio: 
"O nosso café, por muitos anos, foi quase que exclusivamente o nosso artigo de exportação e, portanto, o único sustentáculo de nossa economia e das nossas finanças, sempre teve ali entrada livre, enquanto os países da Europa cobravam impostos de importação de 300 a 1.500 cruzeiros por 60 quilos. Ainda hoje absorvem quase toda nossa produção cafeeira, quase $50 \%$ de nosso comércio exterior" (V: 82).

Por outro lado, no extremo oposto do espectro político-ideológico estavam os socialistas, que na verdade podemos considerar como uma ala esquerda dos "desenvolvimentistas nacionalistas" (dado que estiveram freqüentemente aliados politicamente com estes), diferenciandose destes últimos, dentro outras coisas, pelas seguintes características: a) subordinavam sua plataforma de desenvolvimento capitalista pela via "nacional-desenvolvimentista" no curto prazo, a uma estratégica de transformação social mais ampla, segundo os moldes de organização socioeconômica então vigentes na União Soviética; b) possuíam vínculos organizacionais mais fortes com as massas trabalhadoras e camponesas, e investiam na mobilização popular para "radicalizar" algumas propostas contidas em germe no modelo desenvolvimentista nacionalista - tais como reforma agrária, distribuição de renda e estatização global do aparelho produtivo. No plano do sistema partidário organizado no imediato pós-guerra, esta corrente de pensamento econômico estava representada basicamente pelo PCB e pelos parlamentares da Esquerda Democrática que posteriormente ingressariam no Partido Socialista Brasileiro (PSB) como, por exemplo, Hermes Lima.

Como dissemos, essa corrente pode ser considerada como uma ala esquerda do desenvolvimentismo nacionalista, diferenciando-se desta última pela defesa de uma reforma agrária "radical", e dos interesses mais imediatos dos trabalhadores. Analisando a biografia e a trajetória política de suas principais lideranças, podemos notar que o PCB se diferenciava dos demais partidos representados na Assembléia, tanto do ponto de vista da composição social de sua bancada, quanto sob o aspecto das propostas que defendeu, refletindo-se nestas duas dimensões seu maior compromisso com as lutas operárias e populares. Do ponto de vista de sua composição social, a bancada comunista era integrada por lideranças políticas originárias de movimentos sociais e reivindicatórios das massas populares nas décadas de 1930 e 1940, a maior parte deles tendo militado na AL em 1935-1936, e/ou com passagem pela prisão durante o Estado Novo, e com ligações históricas com movimentos sociais dos trabalhadores manuais, campesinato, estudantes, baixa 
classe média e soldados. Na Constituinte de 1946, as principais lideranças socialistas eram constituídas por parlamentares como o senador comunista Luiz Carlos Prestes (PCB-DF) e pelo advogado e ex-militante da Aliança Nacional Libertadora Hermes Lima, eleito pela coligação Esquerda Democrática/UDN no Distrito Federal.

$\mathrm{Na} 86^{a}$ sessão da Constituinte, realizada em 17 de junho de 1946, o senador Luiz Carlos Prestes proferiu um longo e importante discurso analisando o projeto de Constituição antes de sua votação em plenário, e explicitando vários aspectos de sua plataforma econômica (XIII: 363390). O ponto de partida da análise de Prestes era a caracterização da formação social brasileira como "semi-feudal" (ou seja, com uma agricultura baseada em relações de dependência pessoal e de natureza agroexportadora) e "semi-colonial" (ou seja, dependente). Essas eram as causas básicas da situação de "atraso progressivo" (ou seja, com crescimento econômico e industrial que repunha essa situação estrutural que articulava a dependência econômico-fmanceira do Estado nacional brasileiro com a predominância de relações de produção pré-capitalistas no campo):

"No estudo da persistência dessas relações feudais, apesar da penetração do capitalismo e do imperialismo no Brasil, dessa defesa de um regime pré-capitalista, dessas relações sociais anteriores às relações capitalistas, às relações de salário, às relações de trocas monetárias, devemos buscar as causas de nosso atraso. E vamos encontrar a explicação disso no monopólio da terra, na propriedade privada da terra e na concentração da propriedade" (XII, 374).

Citando trabalho de Roberto Simonsen intitulado $A$ Indústria em face da Economia Nacional, Prestes chama atenção para a deterioração dos termos de intercâmbio gerado pelo caráter latifundiário-exportador e dependente da economia brasileira:

"Tomemos o valor da tonelada importada correspondente ao da tonelada exportada.Veremos que no Brasil, em 1926, o valor médio da tonelada exportada era, em libras, 50.73 e, em 1940, baixou para 9.88, enquanto que a tonelada importada baixava de 16.16 para 7.02 . Quer dizer, comprávamos, em 1926, com uma tonelada exportada, 3.14 toneladas, e em 1940, comprávamos somente 1.41 .

Em 1938, com o valor de uma tonelada exportada, só foi possível adquirir 1.27 toneladas de mercadorias estrangeiras, em vez das 3.14 
de 1926, ou mesmo das 3.00 de 1929. Prejuízo, portanto, de 59\% relativamente a 1929 . O trabalho nacional está sendo dilapidado crescentemente, a terra esgotada e, em troca, torna-se cada vez mais difícil a substituição de aparelhagem, a compra de adubos etc. Um exemplo prático: a máquina que nos custava £500, em 1929, podia ser adquirida em troca da exportação de 11.5 toneladas de nossa exportação, enquanto, em 1938, a mesma máquina, cujo preço já tinha sido reduzido à metade, £250, só pode ser comprada em troca da exportação de 27,2 toneladas de nossa produção [...]

É a desvalorização continuada, é o desperdício, a entrega da riqueza de nosso solo, de nosso trabalho, por valores cada vez menores. Portanto, a depreciação completa de nosso trabalho, o empobrecimento, a pauperização do País, enfim, de toda a fortuna nacional" (XIII: 383 ).

Para Prestes, as causas desse aviltamento progressivo do valor real da moeda nacional vis-à-vis a moeda estrangeira, ou da deterioração dos termos de troca dos produtos nacionais em relação aos estrangeiros, eram o predomínio do latifúndio exportador de commodities no campo brasileiro e o poder de mercado das grandes firmas (financiadoras e exportadoras) estrangeiras, que controlavam o comércio exterior, impedindo que os excedentes produzidos pelo setor exportador fossem internalizados para a criação de um setor de bens de capital tecnologicamente intensivo e autenticamente nacional, que poderia dar origem a um crescimento econômico auto-sustentado e voltado para a ampliação progressiva do mercado interno, incorporando assim no mercado consumidor parcelas crescentes da população assalariada brasileira. De toda esse análise derivava a recomendação de uma ampla reforma agrária, acompanhada da "nacionalização" (isto é, incorporação para o patrimônio do Estado Nacional) progressiva dos setores básicos e estratégicos da economia brasileira. Nos acirrados debates que se travaram na Constituinte por ocasião da votação dos dispositivos que regulamentavam a nacionalização das empresas estrangeiras concessionárias de serviço público e a adoção do critério do "custo histórico" para a avaliação de tais empresas, afirmava o líder comunista:

"Não existe emenda nossa traduzindo qualquer reivindicação de caráter socialista. Sabemos que vivemos numa sociedade capitalista, e hoje, em nosso país, o fundamental é liquidar todos os restos feudais, que estão impedindo o desenvolvimento do capitalismo no 
Brasil. O operariado brasileiro sofre menos do capitalismo do que destes restos feudais, destes atrasos. Ligado a esses atrasos, à classe dominante dos grandes proprietários de terras, está o capital estrangeiro, particularmente através das empresas concessionárias de serviços públicos. Julgamos que os serviços públicos nas mãos do Estado são perfeitamente compatíveis com o capitalismo, e que, em inúmeros países capitalistas, os serviços públicos estão nas mãos do Estado" (XXIII: 185 ).

Nessa demanda de nacionalização de alguns dos setores fundamentais da economia brasileira, Prestes era secundado por Hermes Lima, que num debate afirmava:

"Não é possível desarmar o Estado, nessa altura da vida contemporânea e da transformação social que estamos presenciando, do poder de intervir, de nacionalizar ou de monopolizar.

Mário Masagão [UDN-SP, neoliberal]: É a teoria do nazi-fascismo e do comunismo.

Hermes Lima: Não é isso. O que há é o seguinte: tanto os regimes totalitários como os democráticos podem nacionalizar ou monopolizar, mas nacionalizam e monopolizam com objetivos diferentes e através de técnica diversa. Dizer que nacionalizar é próprio de regime fascista ou comunista não corresponde à realidade do nosso tempo.Vemos a Constituição francesa, repito aqui, liderada pelo Partido majoritário atual na França que é um partido cristão, mas, sobretudo, católico, consagrar o princípio da nacionalização

Mário Masagão: Me manifestei contra a nacionalização já nos debates da Comissão da Constituição porque entendo que o Estado é um mau produtor; que a indústria, nas mãos do Estado, acarreta produção inferior por preço maior." (XXIII: 185)

Ao lado dessas duas correntes de pensamento econômico "extremas" nos debates na Constituinte de 46 , estavam as correntes "intermediárias" cujos pontos de vista foram mais acatados pela maioria parlamentar (embora com taxas diferenciadas de êxito) na redação dos dispositivos constitucionais que regulamentavam as matérias referentes ao futuro modelo de desenvolvimento a ser adotado pelo País no pós-Guerra. Em primeiro lugar, devemos mencionar os desenvolvimentistas nacionalistas, cujas características básicas eram as seguintes, em comparação com outras correntes desenvolvimentistas (Bielschowsky, 1988: 152 e 
passim): a) predomínio da visão de que, pelo menos nos setores fundamentais para a industrialização (energia, transporte, mineração etc), o Estado deveria garantir o controle decisório, deslocando o capital estrangeiro ou impedindo sua entrada; b) desconfiança das possibilidades de se obter um concurso positivo do capital estrangeiro para o projeto de industrialização nacional; c) decidida inclinação pela ampliação da intervenção do Estado na economia, através de políticas de apoio à industrialização integradas, na medida do possível, num sistema de planejamento abrangente e incluindo investimentos estatais em setores básicos.

No plano do sistema partidário esta corrente estava representada por setores minoritários do PSD (principalmente de Estados do Nordeste como Pernambuco, Bahia etc), quase todo 0 PTB, parlamentares isolados de outros partidos, e contava com o apoio do PCB e da Esquerda Democrática. Analisando as biografias desses parlamentares, podemos perceber que, em sua maioria, eram compostas por lideranças políticas que se formaram em razão da expansão da burocracia estatal no pós-trinta, tanto nos institutos e autarquias que regulamentavam vários segmentos das atividades produtivas (IAA, D N etc.), quanto em órgãos de planejamento econômico setorial do governo central, bem como na burocracia estatal ligada ao Ministério do Trabalho.

$\mathrm{Na}$ Constituinte de 1946, o principal líder do "desenvolvimentismo nacionalista" foi o relator-geral da subcomissão de "Ordem Econômica e Social", Agamenon Magalhães, ${ }^{13}$ o qual foi secundado na plataforma de defesa do "desenvolvimentismo-nacionalista" por parlamentares como, por exemplo, Barbosa Lima Sobrinho (PSD-PE), Segadas Viana (PTB-DF)José Joffilli (PSD-PB),Vieira de Melo (PSD-BA) etc, que ocuparam a tribuna com frequência para criticar o liberalismo econômico e afirmar a "inevitabilidade" (bem como a desejabilidade) do intervencionismo estatal na economia para promover o desenvolvimento agro-industrial do país, bem como atenuar ou corrigir os "males do capitalismo", ou seja, da implementação dos modelos neoliberal e desenvolvimentista do setor privado.

Por exemplo, o desenvolvimentista-nacionalista Barbosa Lima Sobrinho, ex-presidente do IAA/Instituto do Açúcar e do Álcool (19381946) e representante da bancada do PSD de Pernambuco liderada por

\footnotetext{
${ }^{13}$ Remetemos o leitor ao artigo que escrevemos anteriormente (Braga, 1996), analisando as atividades de Agamenon Magalhães como relator do título citado, bem como a derrota dos "desenvolvimentistas nacionalistas" no processo de elaboração constitucional.
} 
Agamenon Magalhães, enumerava, na sessão de 19/07/46,alguns fatores que determinavam a inelutabilidade da intervenção do Estado nas sociedades modernas:

"a) O fenômeno da urbanização, a mobilidade dos empregos, a concentração da população em cidades cada vez maiores; b) a passagem do poder econômico da agricultura para a indústria e desta para as finanças; c) a mecanização crescente da produção; d) o progresso vitorioso da tecnologia; e) o aumento de produção, a queda sem precedentes dos coeficientes de mortalidade e de natalidade, com o aumento contínuo da população, a mobilidade dos empregos, a concentração da riqueza e dos controles econômicos, característicos da economia capitalista; f) o aumento da classe média e de seu poder político; g) o aparecimento de um proletariado dotado de consciência de classe. (...) Em suma, transformação completa de toda a sociedade e, com ela, o desenvolvimento do Estado acompanhando essas necessidades novas e evitando que, no mundo, se desenvolva a predominância de uma classe capitalista cada vez mais opressiva e tirânica. Chegamos então à conclusão de que essa intervenção do Estado foi na realidade o meio de que se valeu a democracia para continuar a existir" (XVIII: 412).

O mesmo parlamentar ocupou a tribuna em abril de 1946, para fazer uma longa "Defesa da Ação do Instituto do Açúcar e do Álcool" (VII: 151-162), onde, além de relatar sua gestão à frente da autarquia, aproveitou a ocasião para criticar ferrenhamente o liberalismo econômico e defender a intervenção estatal na economia.

"Muita gente que ataca a economia dirigida fala numa liberdade vaga, imprecisa, numa liberdade que, bem apurada, não é mais que a faculdade para o forte de oprimir ou destruir o fraco. (...) Onde é, afinal, que se respeita o automatismo econômico? Não é evidente que vivemos num sistema de direção? O comércio internacional é controlado pelos trusts, ou regulado pelas tarifas alfandegárias; a moeda é disciplinada pelos Bancos de Emissão do Estado e pelas restrições criadas ao comércio de cambiais; o próprio crédito é também governado pelo Estado, refletindo, não raro, as influências políticas. E ainda há uma série de outros fatores, agindo no domínio econômico e resultantes da interferência do Estado. Aludamos apenas à repercussão do regime tributário, à ação do Estado no domínio dos fretes ferroviários e marítimos, às obrigações da legislação social, às 
medidas de proteção à produção nacional. A lista seria extensa e nos levaria a perguntar o que restaria, dentro de tantas restrições, para o automatismo do fato econômico" (VII: 161).

Segadas Vianna, por exemplo, outro desenvolvimentista nacionalista, um dos principais elaboradores da Consolidação das Leis do Trabalho (CLT) e assessor direto de Marcondes Filho no Ministério do Trabalho, realizou vários pronunciamentos analisando o texto do capítulo da "Ordem Econômica e Social" da Constituição, inclusive tendo censurado a timidez dos redatores do projeto (i.e., Agamenon Magalhães) de promover a nacionalização da economia (XIV, 303-313; XXIII, 42 49). Por exemplo, na sessão de 27/08/46, quando da votação do Projeto Revisto em plenário, comentando a redação dessa parte da Constituição, ele afirmava que:

"No setor estritamente econômico, se há dispositivos que podemos chamar de avançados, como os relativos à intervenção do Estado, sempre que o interesse público o indicar, e ao combate aos trusts e monopólios, verifica-se também um retrocesso, no tocante, por exemplo, à propriedade de minas e de jazidas do subsolo, à nacionalização dos bancos e às companhias de seguro. (...) No projeto submetido ao exame da Casa, entretanto, silencia-se sobre esse direito no sentido de nacionalizar, de estatizar as minas ejazidas do subsolo.

Agamenon Magalhães: O projeto não silencia, porque estabelece o princípio da intervenção no domínio econômico até a monopolizaçâo. Dentro deste princípio, podem ser socializadas ou estatizadas quaisquer minas, quedas d'água ou outras fontes de energia hidráulica. (...)

Segadas Viana: Quanto aos bancos de depósitos e empresas de seguro, a Constituição de 34 também estabelecia, de maneira taxativa, no art. 177, sua nacionalização progressiva. Não se diga que a medida aprovada então, numa Constituição nitidamente democrática, atentava contra os direitos assegurados pela Democracia, pois ainda agora verificamos na Inglaterra a realização do princípio da nacionalização dos bancos e das empresas de seguro" (XXIII: 42-43).

Outra corrente de pensamento econômico representada no sistema partidário do imediato pós-guerra e na Constituinte de 1946 eram os desenvolvimentistas do setor privado. Algumas de suas principais características foram assim enunciadas por Bielschowsky (1988: 93 e passim): a) defesa genérica da planificação da economia e do intervencionismo 
estatal, mas com predomínio da empresa privada e da "livre iniciativa"; b) maior sensibilidade à defesa direta dos interesses empresariais de curto prazo (ou, como diz Bielschowsky, ênfase nas questões que afetavam a lucratividade do capital privado nacional"), tais como proteção à indústria, reação negativa à reivindicações trabalhistas etc.

No plano do sistema partidário, esta corrente era integrada por setores minoritários do PSD, boa parcela da UDN (inclusive de Estados da região nordestina como Pernambuco, Bahia etc), e mesmo por uma minoria do PTB. Analisando a biografia de algumas de suas principais lideranças, podemos perceber que eles possuíam amplas ligações com setores industriais, com segmentos da agro-indústria voltada principalmente para a produção ao mercado interno (usineiros,pecuaristas etc.), e por categorias profissionais cujo status social era derivada da ascensão na hierarquia das unidades produtivas que empregavam equipamento "moderno", tais como várias categorias de engenheiros, técnicos agrícolas etc. Na Constituinte de 1946, as principais lideranças desenvolvimentistas do setor privado foram representadas por Alde Sampaio (UDN-PE), Magalhães Pinto (UDN-MG) e Horácio Lafer (PSD-SP), ${ }^{14}$ todos com ampla militância em associações de classe de setores empresariais. Isso explica também porque, no discurso destes parlamentares, a defesa da industrialização nacional se articula com uma apologia da "livre iniciativa", e com críticas ferrenhas aos dispositivos que asseguravam uma intervenção estatal mais estrita na economia, bem como aos direitos trabalhistas.

Dentre as inúmeras manifestações de representantes dessa corrente de pensamento, por questões de espaço devemos destacar as seguintes, que são bastante representativas do "desenvolvimentismo do setor privado", pois conjugam uma defesa ferrenha da industrialização com uma oposição "no atacado" (dado que "no varejo" esses empresários agro-industriais apoiavam amplamente a regulamentação do Estado na economia) ao "dirigismo estatal" na economia. Por exemplo, najustificativa da emenda supressiva ao artigo que estipulava que "Nenhum ramo da produção nacional poderá receber proteção alfandegária por mais de trinta anos", afirmava Alde Sampaio:

Ao contrário do que afirma Bielschowsky (1988: 96), Roberto Simonsen não foi eleito Constituinte de 1946 pelo PSD, obtendo seu mandato de senador pelo PSD paulista apenas nas eleições suplementares de janeiro de 1947, após o encerramento dos trabalhos constituintes. Essa inexatidão conservou-se na mais recente edição do trabalho do Autor (1998). 
"Com o protecionismo dado à produção brasileira é que se sustentaram os serviços públicos nacionais, as forças armadas e a direção do País. Compartilhando da renda nacional, retirando uma parte dela para aplicação em despesas não-produtivas, é que o Poder Público dispõe de meios para seu sustento e suprimento dos serviços que presta à sociedade. Quanto maior a produção nacional, ainda que artificialmente mantida, em face da concorrência estrangeira, menos onerosa essa parte que se subtrai em prejuízo dos que trabalham e produzem riqueza susceptível de troca.

O poder público brasileiro, que retira mais de $30 \%$ do que se produz anualmente no país para gastos não reprodutivos, ainda que úteis sob outros aspectos, é o mais interessado no protecionismo alfandegário, sem o qual a produção brasileira não poderá se manter.

Um país sem cabedal de produção, sem técnicos em número suficiente para os trabalhos mais indispensáveis na organização industrial, com grande número de recursos para a indústria, inclusive o combustível, dependente de importação estrangeira, não pode ter a veleidade de conservar a sua produção em competição aberta no mercado internacional.

Querendo partir do princípio falso que o protecionismo só se justifica para assegurar vida às indústrias incipientes, o dispositivo do Projeto prescreve arbitrariamente que o período de ensaio se limita a trinta anos. Se todos os demais países permanecessem estabilizados na situação em que se encontram e se se admitisse que esta estagnação perdurasse trinta anos para cada indústria que se estabelece no Brasil, assim talvez fosse acertado o texto do dispositivo.

Tudo isso, porém, é inaceitável, e o que se espera do futuro é uma progresso cada vez maior e mais rápido da fabricação industrial. O Brasil não poderá galgar a situação em quejá se encontram os países que vão na vanguarda do desenvolvimento industrial, e que dispõe de cabedal acumulado em vulto gigantesco. A cada passo que se dê a indústria brasileira, de muitos se avantaja a indústria dos países supercapitalistas, e sem proteção alfandegária a luta nos é desfavorável. Ainda quando por bom aparelhamento, uma indústria brasileira se ponha em condições de igualdade com a industrial estrangeira, a situação geral do país é de tal modo precária que não permite o nosso produto suportar a concorrência do mercado mundial, a despeito das vantagens de nossa mão-de-obra mais barata.

O protecionismo decorre da necessidade de manter campos de atividade que desapareceriam pelo embate da competição travada 
com concorrentes superiormente organizados, em cada caso particular e no geral, e amparados por técnica científica que não se improvisa, onde a instrução é falha e reduzida. O Brasil está no caso de competidor fraco; tirar-lhe o protecionismo é obrigá-1o a retroceder ao tempo de país fornecedor de matérias-primas coloniais, obtidas com trabalho de miséria" (XIII: 292).

Note-se que o autor dessas linhas foi o mesmo que se manifestou ferrenhamente favorável à entrada de capital estrangeiro na economia nacional e à "livre iniciativa", combatendo o intervencionismo estatal na economia - como, por exemplo, no pronunciamento que fez em plenário defendendo emenda supressiva a dispositivo do "anteprojeto Agamenon" que estipulava que "a lei poderia regular a produção e a distribuição segundo critérios definidos pelo poder público":

"Resta, Sr. Presidente, uma única intenção que se poderia descobrir no dispositivo - aquela de querer estabelecer, de modo insidioso, a direção da economia do país; o poder público regularia a produção, circulação e o consumo de bens, por um texto constitucional, o que é arrojo grave para a experiência dos povos. (...) Nem mesmo a Rússia, atualmente o país que mais se tem preocupado com a intervenção do poder público na vida particular - afora a experiência nazista do governo alemão - prescreve a economia total sob a direção do Estado. O poder político tem, realmente, ali, atuação preponderante na vida particular e orienta a ação do indivíduo. Mas, não podendo fugir àquilo que as leis naturais impõem, dá autonomia às empresas, permite o lucro, fornece-lhes recursos para funcionar e cobrajuros desse adiantamentos. Isso porque não é possível sair completamente do âmbito das leis naturais" (XXIII: 99).

Por fim devemos mencionar a corrente que, segundo nosso ponto de vista, foi a corrente de pensamento econômico hegemônica durante os trabalhos da Constituinte de 1946, ou seja, os desenvolvimentistas não-nacionalistas, responsáveis pelas diretrizes programáticas que iriam assegurar a construção da "nova ordem econômica e social" do pós-II Guerra Mundial. Algumas de suas principais características foram enunciadas por Bielschowsky (1988: 122 e passim), destacando-se, para os nossos fins, os seguintes pontos: a) ao contrário dos desenvolvimentistas nacionalistas, os não-nacionalistas vislumbravam a possibilidade de os capitais estrangeiros virem a ter grande participação na produção in- 
dustrial brasileira, ou interesses a longo prazo no processo de industrialização; b) combatiam a excessiva proliferação do intervencionismo e dos investimentos estatais, preferindo o capital estrangeiro ao capital estatal em projetos de industrialização para os quais o capital nacional não tivesse suficiente porte financeiro; c) concepção mais flexível de planejamento.

No plano do sistema partidário, esta corrente era integrada por setores majoritários do PSD que ocuparam os cargos mais importantes na hierarquia da burocracia estatal durante o Estado Novo, especialmente nas cúpulas dos órgãos encarregados da elaboração das diretrizes fundamentais da política econômica, e dos principais organismos estatais criados no período, além de parlamentares isolados de outros partidos que não integravam correntes ideológicas bem articuladas nas respectivas agremiações. No caso da Constituinte de 1946, as mais destacadas lideranças desenvolvimentistas não-nacionalistas (setor público) eram o próprio presidente da Comissão da Constituição, Nereu Ramos (PSD-SC), o ex-ministro da Fazenda, Souza Costa (PSD-RS), e o primeiro presidente da empresa estatal Vale do Rio Doce, Israel Pinheiro (PSD-MG), dentre inúmeros outros próceres pessedistas.

Os desenvolvimentistas não-nacionalistas assemelhavam-se aos nacionalistas em sua defesa do intervencionismo estatal e da conservação da legislação trabalhista; aos desenvolvimentistas do setor privado em sua maior sensibilidade à defesa dos direitos de propriedade (inclusive do latifúndio) e de algumas prerrogativas da "livre iniciativa"; e aos neoliberais em sua postura mais flexível no tocante ao capital estrangeiro. Sublinhe-se que foram essas afinidades e divergências programáticas entre essas diversas correntes que determinaram o complexojogo de polarizações e alianças que estava por trás da dinâmica da luta pela hegemonia na redação dos dispositivos que regulamentavam matéria econômico-financeira, e que permitiu que a resultante do processo político de funcionamento da Constituinte de 1946 fosse a afirmação da hegemonia do desenvolvimentismo não-nacionalista, no plano da direção política do aparelho de Estado, e da burguesia industrial "associada" no plano societal, no contexto da transição mais ampla para o capitalismo no Brasil.

Um das sustentações mais claras da plataforma "desenvolvimentista não-nacionalista" na Constituinte de 1946, encontra-se nos pronunciamentos de Israel Pinheiro (PSD-MG), fazendo a defesa de sua gestão frente à empresa estatal Vale do Rio Doce e analisando os textos do Projeto de Constituição (IX, 265-279; XIX, 210-219), bem como em 
várias de suas emendas sugerindo a atenuação de inúmeros dispositivos "nacional-desenvolvimentistas" do anteprojeto redigido para o título "Ordem Econômica e Social" da Constituição por Agamenon Magalhães ${ }^{15}$. No primeiro desses pronunciamentos, entra numa longa e acirrada polêmica com o senador comunista Luiz Carlos Prestes a respeito do capital estrangeiro, da qual reproduzimos alguns trechos:

"... tendo em vista as deficiências do capital nacional, desejo encarecer a necessidade de que, na futura Constituição, sejam abolidas de vez as restrições ao capital estrangeiro, fruto de um nacionalismo mal compreendido. Os lucros que aqui auferirem, a serem transferidos para o seu país de origem, por maiores que sejam, representarão, no entanto, importância menor do que teremos que transferir da nossa economia para pagamento dos produtos que aqui não poderão ser fabricados por falta desse capital.

Luiz Carlos Prestes: V. Ex. "está a par do que tem sido a exploração do nosso povo pelo capital estrangeiro?

Israel Pinheiro: Estou perfeitamente a par dos grandes benefícios que têm sido prestados ao Brasil pelo capital estrangeiro. Que o digam os nossos melhoramentos, que o digam a industrialização de São Paulo e a da Capital Federal, graças à energia elétrica fornecida pela Light.

Luiz Carlos Prestes: Ninguém nega que a Light tenha seu lado positivo, mas também tem o seu lado negativo.

Israel Pinheiro: Desconheço o lado negativo da Light e, por isso, não desejo discutir, mas afirmo que isso nada tem a ver com a utilização do capital estrangeiro. É uma questão de aplicação das leis brasileiras a assunto. Os benefícios do capital estrangeiro são enormes. Que o digam os Estados Unidos, cuja produção se desenvolveu à custa do capital inglês; que o diga a República Argentina, também. Um país que não dispõe de capitais, ou os tem pelo preço do nosso, não pode progredir ou desenvolver-se. Os senhores comunistas, que não admitem a propriedade privada, estão coerentes com a sua teoria, porque o capital estrangeiro vem fortalecer a propriedade privada e,

Uma excelente síntese do pensamento dessa importantíssima figura da história política e econômica brasileira deste século, bem como de sua atuação parlamentar em todo período do pós-guerra encontra-se em Pinheiro, Israel (1983). Discursos Parlamentares. Brasília: Câmara dos Deputados, Coordenação de Publicações (Col. Perfis Parlamentares, 27). 
portanto, evitar as situações que possam favorecer a expansão de sua doutrina" (IX, 277-278).

O ex-ministro da Fazenda Souza Costa, também foi um dos mais ativos e influentes defensores da entrada de capital estrangeiro na economia nacional durante os trabalhos da Constituinte de 1946. Assim, por exemplo, ao proferir pareceres contrários às emendas deVieira de Melo (PSD-BA) e Luiz Carlos Prestes (PCB-DF) favoráveis à nacionalização das empresas concessionárias de serviço público afirmava:

"Apelo para a Assembléia no sentido de votar rigorosamente contra tal nacionalização, porque deste modo permitiremos a colaboração do capital estrangeiro, que virá acelerar o progresso do Brasil e solucionar nossos problemas, ao invés de fechar as portas do País à colaboração universal. (...) Sou contrário [à adoção do critério do "custo histórico" e à nacionalização das empresas de serviço público] porque adotá-los seria fechar as portas do Brasil à colaboração do capital estrangeiro de que necessitamos; de efetuar ato dejacobinismo prejudicial aos nossos interesses nacionais".

É importante sublinhar, uma vez mais, que essa defesa do capital estrangeiro compatilizava-se com outros elementos do ideário desenvolvimentista-industrializante, tais como a defesa da planificação e do intervencionismo estatal na economia. De resto, muitos elementos do ideário desenvolvimentista não-nacionalista vieram a adquirir maior concretude pouco tempo depois, na elaboração do Plano de Metas de Juscelino Kubitschek, que teve como protagonistas justamente alguns dos parlamentares representantes dessa corrente de pensamento econômico na Constituinte de 1946 , e/ou alguns de seus mais importantes assessores na época.

\section{Principais conclusões}

Assim, como podemos verificar através da análise dos debates parlamentares, o projeto de desenvolvimento econômico "desenvolvimentista associado" era o projeto predominantemente adotado pelas lideranças políticas que ocuparam os postos governamentais mais relevantes no período estadonovista. Ou seja: segundo nosso ponto de vista, esse "desenvolvimentismo não-nacionalista", para utilizar os termos de Bielschowsky, configurava-se como uma linha de força que influenciou 
de maneira preponderante a formatação do padrão de desenvolvimento capitalista da formação social brasileira desde o período de crise final do Estado Novo, como mostram recentemente alguns estudos (Corsi, 2000), bem como da redemocratização de 1945-1946, como nós mesmos procuramos mostrar em outro trabalho (Braga, 1996).

Devido a isso, não podemos avalizar as teses clássicas contidas na bibliografia sobre o período, segundo a qual o governo Kubitschek marcaria, nesse aspecto específico, uma ruptura qualitativa com estratégias de desenvolvimento econômico predominantes em períodos anteriores. A estratégia de desenvolvimento "desenvolvimentista associada" sempre esteve presente de maneira predominante no horizonte político dos segmentos hegemônicos das classes dominantes brasileiras, desde pelo menos a crise final do regime estadonovista, embora ela se concretizasse com graus variáveis de êxito e de intensidade nas diversas conjunturas históricas que configuraram a história política e econômica do pós-Segunda Guerra no Brasil.

Por fim, podemos enunciar sinteticamente as principais conclusões que derivam das idéias apresentadas anteriormente:

- Segundo nosso ponto de vista, a utilização correta do método "prosopográfico" não deve se limitar a um sociografia descritiva dos agentes políticos e econômicos, mas sim servir de base de apoio para uma análise menos "agregada" do conteúdo da ação política dos atores observados;

A aplicação desse método a nosso objeto de estudo - ou seja, aos conflitos travados pelas vanguardas político-partidárias atuantes no Parlamento, auxiliou-nos a tipificar uma dimensão do comportamento político dos atores atuantes nesse processo, vale dizer, seu pertencimento às principais correntes de pensamento econômico existentes no período;

Verificamos a presença, no discurso desses atores, de argumentos de natureza idêntica ou análoga aos argumentos apresentados pelas cinco correntes de pensamento economico definidas por Ricardo Bielschowsky em seu trabalho (neoliberal, desenvolvimentistas do setor privado; nacionalistas do setor público; não-nacionalistas do setor público; e "socialistas");

Esse exame nos permitiu reiterar e detalhar conclusões já enunciadas em outros trabalhos acerca do predomínio de uma dessas correntes (i. e., o desenvolvimentismo não-nacionalista) sobre as demais, na medida em que suas propostas foram as mais acatadas pela maioria do parlamento constituinte, fornecendo assim uma base de 
apoio parlamentar para as medidas de política econômica que eram implementadas pelos órgãos governamentais encarregados da implementação da política econômica na época (Ministério da Fazenda, S UMOC, Banco do Brasil etc);

- Esta foi a estratégia de desenvolvimento predominantemente adotada pelas autoridades governamentais que ocupavam os centros de poder do sistema político brasileiro naquela quadra história, na medida em que legitimou, mesmo antes do Plano de Metas, o intervencionismo estatal industrializante articulado a um maior grau de abertura da economia para o capital estrangeiro.

\section{Referências bibliográficas}

Abreu, Alzira Alves de; Beloch, Israel; Lamarão, Sérgio Tadeu de Niemeyer; LattmanWeltman, Fernando (coords.). Dicionário Histórico-Biográfico Brasileiro pós-30. Rio de Janeiro: FGV, 2001, 5 vols.

Abreu,Marcelo de Paiva. "Crise, crescimento e modernização autoritária: 1930-1945". In: Abreu, M.P. (org.) A Ordem no Progresso: cem anos de política econômica republicana. 4 ed. Rio de Janeiro: Ed. Campus, 1994.

Bielschowsky, Ricardo. Pensamento Econômico Brasileiro: o ciclo ideológico do desenvolvimentismo. Série PNPE, $\mathrm{N}^{\circ}$ 19, Rio de Janeiro: IPEA, 1988.

Braga, Sérgio Soares. "A Constituinte de 1946 e a nova ordem econômica e social do pós-II Guerra Mundial". Revista de Sociologia e Política (6/7), jul-dez 1996:7-24.

. Quem foi Quem na Assembléia Constituinte de 1946; um perfil

socioeconômico e regional da Constituinte de 46. Brasília: Câmara dos Deputados, Coordenação de Publicações, 1998.Versão on-line: camara.gov.br $\longrightarrow$ [Documentação e Informação] $\rightarrow$ [Publicações] $\rightarrow$ [Publicações Eletrônicas].

Brasil. Câmara dos Deputados. Anais da Assembléia Constituinte de 1946 e Diários do Congresso Nacional. Rio de Janeiro: Imprensa Nacional (Disponíveis on-line, na íntegra, no sítio da Câmara dos Deputados).

Corsi, Francisco Luiz. Os Rumos da Economia Brasileira no Final do Estado Novo (19421945). Campinas: IE/Unicamp,Tese de Mestrado, 1991.

Unesp, 2000.

Estado Novo; política externa e projeto nacional. São Paulo: Editora

Malan, Pedro Sampaio et. al. Política Econômica Externa e Industrialização no Brasil: 19391952. 2.ed. Rio de Janeiro: IPEA/INPE, 1980.

Miceli, Sérgio. "Carne e osso da elite política brasileira pós-1930". In: Fausto, Bóris. (org.). História Geral da Civilização Brasileira, Tomo III - O Brasil Republicano, v. 3 - Sociedade e Política. (1930-1964). 3. ed., São Paulo: Difel, 1986, pp. 557-596.

Pinheiro, Israel. Discursos Parlamentares. Brasília: Câmara dos Deputados, Coordenação de Publicações (Col. Perfis Parlamentares, 27), 1983.

Stone, Lawrence. "Prosopography". In: Gilbert, Felix \& Graubard, Stephen (eds.). Historical Studies Today. New York: W.W. Norton \& Company, 1972,pp. 107-140. 
Apêndice: Algumas das principais lideranças políticas envolvidas no debate econômico na conjuntura da redemocratizaçäo 1945-1946

\begin{tabular}{|c|c|c|c|c|}
\hline $\begin{array}{l}\text { Parlamentar } \\
\text { e partido }\end{array}$ & $\begin{array}{l}\text { Corrente(s) } \\
\text { de pensamento } \\
\text { cconômico }\end{array}$ & $\begin{array}{l}\text { Atividades } \\
\text { profissiomans }\end{array}$ & $\begin{array}{l}\text { Ligraçōes com } \\
\text { instituiçōes } \\
\text { e movimentos } \\
\text { socinis }\end{array}$ & Postira parlamentar \\
\hline $\begin{array}{l}\text { Daniel de } \\
\text { Carvalho } \\
\text { (l'R/MG) }\end{array}$ & Neoliberal & $\begin{array}{l}\text { Banqueiro, } \\
\text { empresário } \\
\text { e advogndo }\end{array}$ & $\begin{array}{l}\text { Vace-presidente da } \\
\text { A(:KJ/Associacĩo } \\
\text { Comercial do Rio } \\
\text { de Janciro (1)42\% } \\
1945) \text {; Presidente } \\
\text { do Instituto de } \\
\text { Economia e de } \\
\text { Pesquisas Econô- } \\
\text { micas da ACRJ } \\
(1943-1946)\end{array}$ & $\begin{array}{l}\text { - crítico ferrenho do inter- } \\
\text { vencionismo estatal e da } \\
\text { política de desenvolvimen- } \\
\text { to da Fra Vargas; - adepto } \\
\text { da teoria das "vantagens } \\
\text { comparativas" e receitas } \\
\text { "ortodoxas" de combate à } \\
\text { inflaçĩo }\end{array}$ \\
\hline $\begin{array}{l}\text { Artur } \\
\text { Bernardes } \\
(\mathrm{PR} / \mathrm{M} G)\end{array}$ & Neoliberal & $\begin{array}{l}\text { Proprietátio } \\
\text { de terras (ca- } \\
\text { feicultor e } \\
\text { usinciro na } \\
\text { região da } \\
\text { Zona da Mata } \\
\text { mineira, e } \\
\text { advogado }\end{array}$ & Seln informaçào & $\begin{array}{l}\text { - crítico do intervencio- } \\
\text { nismo estatal implemen- } \\
\text { tado no pós-30 em geral } \\
\text { da política das autarquias } \\
\text { em particular, manifcstou- } \\
\text { se favorável à extinção de } \\
\text { todas as autarquias regula- } \\
\text { doras dos mercados de pro- } \\
\text { dutos primários; - parado- } \\
\text { xalmente, foi a favor da } \\
\text { intervenção do Estado no } \\
\text { domínio da exploração do } \\
\text { Petróleo, sendo o único } \\
\text { parlamentar de seu parti- } \\
\text { do a mataifestar tal posiço }\end{array}$ \\
\hline $\begin{array}{l}\text { Bernardes } \\
\text { Filloo } \\
\text { (PR/MGi) }\end{array}$ & Neoliberal & $\begin{array}{l}\text { Banqueiro, } \\
\text { proprictário } \\
\text { de terras e } \\
\text { advogado }\end{array}$ & $\begin{array}{l}\text { Ptesidente do } \\
\text { Banco do } \\
\text { Comćrcio S.A.e } \\
\text { da Companhia } \\
\text { Boavista de } \\
\text { Seguros }\end{array}$ & $\begin{array}{l}\text { - combateu a nacionaliza- } \\
\text { ço das empresas de segu- } \\
\text { to e capitalizaçấ e foi a } \\
\text { favor da participaçào do } \\
\text { capital estrangeiro no sis- } \\
\text { tema bancário nacional }\end{array}$ \\
\hline $\begin{array}{l}\text { Sampaio } \\
\text { Vidal } \\
\text { (PSD/SP) }\end{array}$ & Neoliberal & $\begin{array}{l}\text { Cafeicultor } \\
\text { e empresário }\end{array}$ & $\begin{array}{l}\text { Presidente da } \\
\text { Socicdade Rural } \\
\text { Bnsileira dumnte } \\
\text { o Estado Novo } \\
(1943-1945)\end{array}$ & $\begin{array}{l}\text { - critico ferrenho do inter- } \\
\text { vencionismo estatal; } \\
\text { - anyplamente favorável à } \\
\text { entrada de capital estran- } \\
\text { geiro na econômica }\end{array}$ \\
\hline $\begin{array}{l}\text { Clemente } \\
\text { Mariani } \\
\text { (UDN/BA) }\end{array}$ & $\begin{array}{l}\text { Ncoliberal; } \\
\text { desenvolvimen- } \\
\text { tista do } \\
\text { setor privado }\end{array}$ & $\begin{array}{l}\text { Banqueiro e } \\
\text { proprietário } \\
\text { de terras }\end{array}$ & $\begin{array}{l}\text { Diretor da Associa- } \\
\text { ção Comercial } \\
\text { da Bahia }\end{array}$ & $\begin{array}{l}\text { - critica ao intervencio- } \\
\text { nismo estatal e aos direitos } \\
\text { sociais dos trabalhadores; } \\
\text { - defesa de obras de infra- } \\
\text { estrutura regional }\end{array}$ \\
\hline
\end{tabular}




\begin{tabular}{|c|c|c|c|c|}
\hline $\begin{array}{l}\text { Parlamentar } \\
\text { e partido }\end{array}$ & $\begin{array}{l}\text { Corrente(s) } \\
\text { de pensamento } \\
\text { economico }\end{array}$ & $\frac{\text { Atividades }}{\text { profissionais }}$ & $\begin{array}{l}\text { Ligações com } \\
\text { instituições } \\
\text { e movimentos } \\
\text { sociais }\end{array}$ & Postura parlamentar \\
\hline $\begin{array}{l}\text { Jales } \\
\text { Machado } \\
\text { ( UDN/GO) }\end{array}$ & Neoliberal & $\begin{array}{l}\text { Cafeicultor, } \\
\text { empresário e } \\
\text { engenheiro }\end{array}$ & $\begin{array}{l}\text { Sem informação } \\
\text { sobre vínculos } \\
\text { com associações } \\
\text { de classe }\end{array}$ & $\begin{array}{l}\text { - crítica ao intervencio- } \\
\text { nismo estatal e favorável à } \\
\text { extinção do Departamen- } \\
\text { to Nacional do Café }\end{array}$ \\
\hline $\begin{array}{l}\text { Magalhães } \\
\text { Pinto } \\
\text { ( UDN/M G) }\end{array}$ & $\begin{array}{l}\text { Desenvolvi- } \\
\text { mentista } \\
\text { setor privado }\end{array}$ & Banqueiro & $\begin{array}{l}\text { Presidente da } \\
\text { Federação do } \\
\text { Comercio de Minas } \\
\text { Gerais (1939) }\end{array}$ & $\begin{array}{l}\text { - crítica ao intervencionis- } \\
\text { mo e à política de desen- } \\
\text { volvimento do Estado } \\
\text { Novo; - crítica ferrenha } \\
\text { aos direitos sociais }\end{array}$ \\
\hline $\begin{array}{l}\text { Alde } \\
\text { Sampaio } \\
\text { (UDN/PE) }\end{array}$ & $\begin{array}{l}\text { Desenvolvi- } \\
\text { mentista do } \\
\text { setor privado }\end{array}$ & $\begin{array}{l}\text { Usineiro e } \\
\text { proprietário } \\
\text { de terras }\end{array}$ & $\begin{array}{l}\text { Durante o Estado } \\
\text { Novo foi represen- } \\
\text { tante dos usineiros } \\
\text { pernambucanos na } \\
\text { Comissão Executiva } \\
\text { do IAA (1938- } \\
\text { 1941); } \bullet \text { militou em } \\
\text { várias associações } \\
\text { de classe empresa- } \\
\text { riais (HEP;ACRJ; } \\
\text { CNI etc.) }\end{array}$ & $\begin{array}{l}\text { - combateu veemente- } \\
\text { mente o intervencionis- } \\
\text { mo estatal e o modelo de } \\
\text { desenvolvimento econô- } \\
\text { mico implementado du- } \\
\text { rante o Estado Novo; } \\
\text { - propôs várias emendas } \\
\text { eliminando direitos sociais } \\
\text { dos trabalhadores }\end{array}$ \\
\hline $\begin{array}{l}\text { Horácio } \\
\text { Láfer } \\
\text { (PSD/SP) }\end{array}$ & $\begin{array}{l}\text { Desenvolvi- } \\
\text { mentista do } \\
\text { setor privado }\end{array}$ & Industrial & $\begin{array}{l}\text { Diretor do CIEP e } \\
\text { da FIESP, e membro } \\
\text { do Conselho Téc- } \\
\text { nico de Economia } \\
\text { e Finanças durante } \\
\text { o Estado Novo }\end{array}$ & $\begin{array}{l}\text { - apoio a política econô- } \\
\text { mico-financeira do Estado } \\
\text { Novo mas preocupou-se } \\
\text { em antepor limites à ação } \\
\text { estatal; - combateu direitos } \\
\text { sociais }\end{array}$ \\
\hline $\begin{array}{l}\text { Nereu } \\
\text { Ramos } \\
\text { (PSD/SC) }\end{array}$ & $\begin{array}{l}\text { Desenvolvi- } \\
\text { mentista } \\
\text { não-nacionalista }\end{array}$ & Advogado & $\begin{array}{l}\text { Interventor em } \\
\text { Santa Catarina } \\
\text { durante o Estado } \\
\text { Novo (1937-1945) }\end{array}$ & $\begin{array}{l}\text { - nao participou direta- } \\
\text { mente do debate sobre te- } \\
\text { mas econômicos, mas teve } \\
\text { papel decisivo na criação } \\
\text { das condições políticas que } \\
\text { asseguraram a aprovação } \\
\text { dos dispositivos desen- } \\
\text { volvimentistas não-nacio- } \\
\text { nalistas }\end{array}$ \\
\hline $\begin{array}{l}\text { Israel } \\
\text { Pinheiro } \\
\text { (PSD/MG) }\end{array}$ & $\begin{array}{l}\text { Desenvolvi- } \\
\text { mentista } \\
\text { não-nacionalista }\end{array}$ & $\begin{array}{l}\text { Industrial, } \\
\text { proprietário } \\
\text { de terras e } \\
\text { engenheiro }\end{array}$ & $\begin{array}{l}\text { Secretário da } \\
\text { Agricultura, In- } \\
\text { dústria e Comércio } \\
\text { do estado de MG } \\
\text { durante o Estado } \\
\text { Novo (1937-1942) } \\
\text { e o primeiro pre- } \\
\text { sidente da empresa } \\
\text { estatal de minera- } \\
\text { ção Vale do Rio } \\
\text { Doce (1942-1945) }\end{array}$ & $\begin{array}{l}\text { - defendeu o intervencio- } \\
\text { nismo estatal, o planeja- } \\
\text { mento econômico e a } \\
\text { entrada de capital estran- } \\
\text { geiro em setores estraté- } \\
\text { gicos da economia nacio- } \\
\text { nal; - opositor ferrenho da } \\
\text { reforma agrária e da distri- } \\
\text { buição da propriedade da } \\
\text { terra no campo brasileiro }\end{array}$ \\
\hline
\end{tabular}




\begin{tabular}{|c|c|c|c|c|}
\hline $\begin{array}{l}\text { Parlamentar } \\
\text { e partido }\end{array}$ & $\begin{array}{l}\text { Cotrente(s) } \\
\text { se pensamento } \\
\text { econômico }\end{array}$ & $\begin{array}{l}\text { Atividades } \\
\text { profissiomais }\end{array}$ & $\begin{array}{l}\text { Ligaçōes com } \\
\text { inzstituiçòes } \\
\text { e movimentos } \\
\text { sociais }\end{array}$ & Postura parlamentar \\
\hline $\begin{array}{l}\text { Souza Costa } \\
\text { (PSD/MG) }\end{array}$ & $\begin{array}{l}\text { Desenvolvi- } \\
\text { mentista } \\
\text { não-nacionalista }\end{array}$ & $\begin{array}{l}\text { Bunqueiro e } \\
\text { funcionatio } \\
\text { píblico }\end{array}$ & $\begin{array}{l}\text { Durante o Estado } \\
\text { Novo foi ministro } \\
\text { da I azenda, sendo } \\
\text { anda lioje o minis- } \\
\text { tro a permanecer } \\
\text { por mais tenpo no } \\
\text { cargo na história } \\
\text { brasileira } \\
(1934-1945)\end{array}$ & $\begin{array}{l}\text { - presidente da Subcontis- } \\
\text { são "Discriminação de } \\
\text { Rendas" da Comissão da } \\
\text { Constituição, teve papel } \\
\text { decisivo na redação de } \\
\text { vários dispositivos consti- } \\
\text { tucionais que regulavam } \\
\text { turéria econônico-finan- } \\
\text { ceira; - defensor ferrenho } \\
\text { e articulado da política } \\
\text { econômica implementada } \\
\text { durante o Estado Novo, } \\
\text { bem como da entrada de } \\
\text { capital estrangeiro na eco- } \\
\text { nomia nacional }\end{array}$ \\
\hline $\begin{array}{l}\text { Benedito } \\
\text { Valadares } \\
\text { (PSD/MG) }\end{array}$ & $\begin{array}{l}\text { Desenvolvi- } \\
\text { mentista } \\
\text { não-nacionalista }\end{array}$ & Advogado & $\begin{array}{l}\text { Dutante o Estado } \\
\text { Novo foi } \\
\text { interventor federal } \\
\text { em MG e uma dis } \\
\text { principais } \\
\text { lideranças do } \\
\text { tegime }\end{array}$ & $\begin{array}{l}\text { - amplamente favorável } \\
\text { lo intervenciomismo esta- } \\
\text { tal c ì cntmda de capital } \\
\text { cstringeiro na economia } \\
\text { lrasileirn; - apresentou } \\
\text { várias emendas e suges- } \\
\text { tões atenuando dispositi- } \\
\text { vos "desenvolvimentistas } \\
\text { nacionalistas" do "ante- } \\
\text { projeto Agamenon" }\end{array}$ \\
\hline $\begin{array}{l}\text { Costa Neto } \\
\text { (PSD/SP) }\end{array}$ & $\begin{array}{l}\text { Desenvolvi- } \\
\text { mentista } \\
\text { não-nacionalista }\end{array}$ & $\begin{array}{l}\text { Advogado } \\
\text { e jornalista }\end{array}$ & $\begin{array}{l}\text { Procurador-geral } \\
\text { de Sào Paulo na } \\
\text { gestāo do } \\
\text { interventor } \\
\text { Fernando Costa } \\
(1941-1943)\end{array}$ & $\begin{array}{l}\text { - um dos principais ope- } \\
\text { radores parlamencares da } \\
\text { fase inicial do governo } \\
\text { Dutra, teve papel decisivo } \\
\text { na aprovação da Carta de } \\
1946 \text { e da aprovação de } \\
\text { varios de seus dispositivos } \\
\text { desenvolvimentistas não- } \\
\text { nacionalistas en plenário; } \\
\text { - combateu veemente- } \\
\text { mente a retorma agrária e } \\
\text { as organizaçōes sindicais } \\
\text { dos trabalhadotes }\end{array}$ \\
\hline $\begin{array}{l}\text { Agamenon } \\
\text { Magalhàcs } \\
\text { (PSD/PE) }\end{array}$ & $\begin{array}{l}\text { Desenvolvi- } \\
\text { mentista } \\
\text { nacionalista }\end{array}$ & $\begin{array}{l}\text { Advogado, } \\
\text { funcionário } \\
\text { público e } \\
\text { jornalista }\end{array}$ & $\begin{array}{l}\text { Durante o Estado } \\
\text { Novo foi interven- } \\
\text { tor federal em } \\
\text { Pernambuco } \\
(1937-1945) \text { e } \\
\text { ministro da Justiça, } \\
\text { tcndo nessa con- } \\
\text { dição decretado } \\
\text { a "Iei Malaia" }\end{array}$ & $\begin{array}{l}\text { - principal liderança ua- } \\
\text { cional-desenvolvimentista } \\
110 \text { parlamento, foi o reda- } \\
\text { tor do ante-projeto do tí- } \\
\text { tulo Ordem Economica c } \\
\text { Social da nova Constitui- } \\
\text { tuição, que iria sofrer inú- } \\
\text { meras emendas durante } \\
\text { sua discussão em plenário }\end{array}$ \\
\hline
\end{tabular}




\begin{tabular}{|c|c|c|c|c|}
\hline $\begin{array}{l}\text { Parlamentar } \\
\text { e partido }\end{array}$ & $\begin{array}{l}\text { Corrente(s) } \\
\text { de pensamento } \\
\text { economico }\end{array}$ & $\begin{array}{l}\text { Atividades } \\
\text { profissionais }\end{array}$ & $\begin{array}{l}\text { Ligações com } \\
\text { instituições } \\
\text { e movimentos } \\
\text { sociais }\end{array}$ & Postura parlamentar \\
\hline $\begin{array}{l}\text { Segadas } \\
\text { Viana } \\
(\text { PTB/DF) }\end{array}$ & $\begin{array}{l}\text { Desenvolvi- } \\
\text { mentista } \\
\text { nacionalista }\end{array}$ & $\begin{array}{l}\text { Advogado, } \\
\text { funcionário } \\
\text { público e } \\
\text { jornalista }\end{array}$ & $\begin{array}{l}\text { Durante o Estado } \\
\text { Novo foi um dos } \\
\text { principais assessores } \\
\text { do ministro do } \\
\text { Trabalho, } \\
\text { Marcondes Filho, } \\
\text { tendo participado } \\
\text { intensamente na } \\
\text { elaboração da CLT }\end{array}$ & $\begin{array}{l}\text { * defensor ativo e articula- } \\
\text { do da política de desenvol- } \\
\text { vimento e da política so- } \\
\text { cial implantada durante o } \\
\text { Estado Novo; - defendeu } \\
\text { a restauração dos disposi- } \\
\text { tivos nacional-desenvolvi- } \\
\text { mentistas das Cartas de } \\
1934 \text { e } 1937 \text {, tendo sido } \\
\text { derrotado em ambas as de- } \\
\text { mandas; }\end{array}$ \\
\hline $\begin{array}{l}\text { Barbosa } \\
\text { Lima } \\
\text { Sobrinho } \\
(\text { PSD/PE) }\end{array}$ & $\begin{array}{l}\text { Desenvolvi- } \\
\text { mentista } \\
\text { nacionalista }\end{array}$ & $\begin{array}{l}\text { Jornalista } \\
\text { e advogado. } \\
\text { funcionário } \\
\text { público }\end{array}$ & $\begin{array}{l}\text { Presidente do } \\
\text { IAA/Instituto do } \\
\text { Açúcar e do Álcool } \\
\text { durante todo o } \\
\text { Estado Novo } \\
\text { (1937-1945) }\end{array}$ & $\begin{array}{l}\text { - defensor da interven- } \\
\text { ção do estado na econo- } \\
\text { mia e crítico do capital } \\
\text { estrangeiro, acompanhou } \\
\text { Agamenon Magalhães em } \\
\text { seus posicionamentos na- } \\
\text { cional-desenvovimentistas }\end{array}$ \\
\hline $\begin{array}{c}\text { José Joffily } \\
\text { (PSD/PB) }\end{array}$ & $\begin{array}{l}\text { Desenvolvi- } \\
\text { menrista } \\
\text { nacionalista }\end{array}$ & $\begin{array}{l}\text { Advogado, } \\
\text { funcionário } \\
\text { público }\end{array}$ & $\begin{array}{l}\text { Secretário de Agri- } \\
\text { cultura,Viação e } \\
\text { Obras Públicas na } \\
\text { gestão do } \\
\text { intervento Rui } \\
\text { Carneiro na Paraíba } \\
\text { (1942-1945) }\end{array}$ & $\begin{array}{l}\text { - defensor ativo da inter- } \\
\text { venção do Estado para } \\
\text { promover a industrializa- } \\
\text { ção do país bem como a } \\
\text { atenuação das desigualda- } \\
\text { des regionais; - favorável à } \\
\text { que a proposta (derrotada) } \\
\text { de se conceder privilégio } \\
\text { ao Estado na exploração de } \\
\text { jazidas minerais encontra- } \\
\text { das no subsolo de terras } \\
\text { que fosse de propriedade } \\
\text { privada }\end{array}$ \\
\hline $\begin{array}{l}\text { Luis Carlos } \\
\text { Prestes } \\
(\mathrm{PCB} / \mathrm{DF})\end{array}$ & Socialista & $\begin{array}{l}\text { Engenheiro } \\
\text { militar }\end{array}$ & $\begin{array}{l}\text { Preso político du- } \\
\text { rante todo o Estado } \\
\text { Novo (1937-1945) }\end{array}$ & $\begin{array}{l}\text { - defensor do interven- } \\
\text { cionismo estatal e de po- } \\
\text { líticas distributivas }\end{array}$ \\
\hline $\begin{array}{l}\text { Hermes } \\
\text { Lima } \\
(\text { ED/DF) }\end{array}$ & Socialista & $\begin{array}{l}\text { Advogado } \\
\text { e professor } \\
\text { universitário }\end{array}$ & $\begin{array}{l}\text { Perseguido político } \\
\text { durante a ditadura } \\
\text { estadonovista foi } \\
\text { um dos principais } \\
\text { intelectuais socia- } \\
\text { lista do pós-trinta }\end{array}$ & $\begin{array}{l}\text { - defendeu uma industria- } \\
\text { lização acelerada articula- } \\
\text { da à reforma agrária e polí- } \\
\text { ticas redistributivistas }\end{array}$ \\
\hline
\end{tabular}

